\title{
Mari Mossberg
}

\section{Finns det kvinnliga astronauter? Om könsneutral och inkluderande översättning av faktaböcker för barn}

\author{
Are There Any Female Astronauts? On Gender-Inclusive Transla- \\ tion of Non-Fiction Books for Children
}

\begin{abstract}
This article deals with gender-inclusive translation of information books for children. Translation solutions drawn from three non-fiction books translated from French to Swedish by different translators are discussed in terms of gender neutrality and inclusion. Analysis reveals that, although the Swedish translations are comparatively free in relation to the original texts, the translators differ in their tendency to make use of genderinclusive translation strategies, such as employing gender-neutral occupational terms, avoiding masculine generic forms, reformulating genderbiased passages, representing parenthood as more equal and making women visible in the translation by the explicit mention of female experiences and characters. While emphasizing the importance of being attentive to gender issues in information books for young children, it is argued that genderneutralising interventions can be made in translations of this text type without putting the overall purpose of the book at risk.
\end{abstract}

Keywords: translation, Swedish, French, information books, nonfiction, gender inclusive, gender neutrality, gender-biased language, translation strategy

(C)2021 M. Mossberg. This is an open access article distributed under the terms of the Creative Commons CC-BY-NC 4.0 License (https:// creativecommons.org/licenses/by-nc/4.0/), permitting all non-commercial use, distribution, and reproduction in any medium, provided the original work is properly cited.

Citation: Barnboken - tidskrift för barnlitteraturforskning/Barnboken: Journal of Children's Literature Research, Vol. 44, 2021 http://dx.doi.org/10.14811/clr.v44.563 
Utgivningen av faktaböcker för barn har ökat markant de senaste årtiondena. Enligt Svenska barnboksinstitutets Bokprovning årgång $2020(27-28,37,39)$ var 346 titlar eller $17 \%$ av alla barn- och ungdomsböcker som gavs ut i Sverige år 2020 klassificerade som faktaböcker, och av dessa var cirka 55 \% översatta. Det betyder att majoriteten av de faktaböcker som ges ut i Sverige bär spår av ett annat språk och en främmande kultur. Denna import är i allra högsta grad berikande för den svenska barnlitteraturen, men det är också viktigt att de främmande inslagen blir föremål för granskning och diskussion.

Vid en första anblick är det lätt att få uppfattningen att faktaböcker för barn förmedlar en objektiv och "sann" bild av verkligheten och att översättaren bara behöver överföra rena fakta från ett språk till ett annat - men så enkelt är det sällan. Även i faktatexter är det någon som tagit ställning till vilket stoff som ska tas med, ur vilket perspektiv det ska presenteras, vilka formuleringar som bäst beskriver innehållet och vilka bilder som ska samspela med texten. Alla dessa val leder med nödvändighet till att texten färgas av en viss ideologisk syn. När rättigheterna till boken i ett senare skede säljs till andra länder köper förlaget $i$ allmänhet ett färdigt paket, där bilder, layout och faktaurval redan är fastlagt (jfr O'Sullivan 101-102, om internationella samproduktioner). Det finns alltså inte mycket man då kan göra för att ändra den ideologiska vinklingen i den delen av materialet. Däremot verkar översättningen av löptexten inte styras av lika strikta normer. Ibland ser man exempelvis att information rättas eller uppdateras i översättningen, och i vissa fall lokaliseras faktatexten för att bättre passa in i den nya kulturkontexten (O'Sullivan 102). Det kan vara passager med geografiskt, historiskt eller samhälleligt innehåll som skrivs om så att de speglar förhållandena i målspråkskulturen, men det kan även röra sig om mer subtila förändringar som språkliga förskjutningar vid beskrivningen av ideologiskt laddade ämnen (jfr Mossberg). Ett sådant känsligt område är synen på kön och genusfrågor, det vill säga hur kön skildras, hur ofta och i vilka sammanhang könsbestämda personer förekommer i bild och text samt vilka könskategoriserande formuleringar som används.

Språk och kön har debatterats flitigt i Sverige under de senaste årtiondena och det har resulterat $i$ ett stort antal råd och anvisningar om könsneutralt skrivande och inkluderande framställningssätt i offentliga texter (Myndigheternas skrivregler, avsnitt 8.1; Språkriktighetsboken 73-96; Milles). Anvisningarna är inte tvingande, men i Myndigheternas skrivregler står det att de "bör [...] eftersträvas" och att könsneutrala pronomen och yrkesbeteckningar "är särskilt vik- 
tiga när kön är ovidkommande och när man vill vara säker på att inkludera alla mottagare av en text" (66). De offentliga råden om könsneutralt skrivande gäller visserligen bara myndighetstexter som vänder sig till vuxna, men att de även skulle kunna appliceras på faktaböcker för barn kan motiveras utifrån de svenska läroplanerna för grundskolan och för förskolan, vilka numera har tydliga riktlinjer för hur skolan, och underförstått hela det svenska samhället, ska främja jämställdhet och aktivt motverka könsmönster som begränsar barns utvecklingsmöjligheter och livsval. I den svenska läroplanen för förskolan kan man bland annat läsa följande:

Förskolan ska aktivt och medvetet främja alla barns lika rättigheter och möjligheter, oberoende av könstillhörighet. Förskolan har ett ansvar för att motverka könsmönster som begränsar barnens utveckling, val och lärande. Hur förskolan organiserar utbildningen, hur barnen blir bemötta samt vilka krav och förväntningar som ställs på barnen bidrar till att forma deras uppfattningar om vad som är kvinnligt och manligt. (Skolverket, Läroplan för förskolan 7)

Att språket är en viktig del i socialisationen och spelar en avgörande roll för vilka "uppfattningar" barn skapar "om vad som är kvinnligt och manligt" kan i sin tur förklaras med följande citat ur Språk och kön (2007):

Om man utgår från att språksystemet med dess ordförråd och grammatiska strukturer innehar denna aktiva roll för vår förståelse av omvärlden, så är det av största vikt vilka ord vi använder för att beskriva verklighetens karaktär. Språket bidrar nämligen till att både skapa och stärka de kulturella föreställningar som är knutna till vår kategorisering av kön. (Edlund m.fl. 204)

Trots att de svenska läroplanerna uttrycker höga ambitioner om att "aktivt och medvetet främja alla barns lika rättigheter och möjligheter, oberoende av könstillhörighet" (Skolverket, Läroplan för förskolan 7) har flera granskningar av den svenska skolans läromedel visat att könsrelationer sällan tematiseras i läromedlen och att kvinnor och kvinnors erfarenheter fortfarande i hög grad osynliggörs, i text såväl som i bild (Graeske; Ohlander, Kvinnor, män och jämställdhet i läromedel $i$ historia och Kvinnor, män och jämställdhet i läromedel $i$ samhällskunskap; Skolverket, I enlighet med skolans värdegrund?). Hur skildringen av kön ser ut i svenska faktaböcker som används utanför skolans regi verkar däremot inte ha undersökts närmare, vare sig i originalskrivna svenska eller i översatta faktaböcker. 
I den här artikeln angriper jag frågan ur ett översättningsvetenskapligt perspektiv och presenterar ett antal könsrelaterade svårigheter som kan uppkomma vid översättningen av icke skönlitterära texter för barn. Diskussionen tar avstamp i granskningen av tre franska faktaböcker och deras svenska översättningar. Skildringen av kön i källtextmaterialet analyseras och jämförs med de svenska måltexterna, samtidigt som strategier för könsneutral och inkluderande översättning presenteras och problematiseras. Ett övergripande mål med artikeln är att resonera om möjligheterna och hindren för könsneutral och inkluderande översättning av faktaböcker för barn och argumentera för att det i många fall är möjligt att undvika könsstereotypa framställningar utan alltför stora avvikelser i förhållande till källtexten.

\section{Språk och kön i översättningsvetenskapen}

Frågan om barnboksöversättarens handlingsfrihet leder tillbaka till den klassiska meningsstriden om översättarens trohet eller otrohet mot originalet (se t.ex. Nikolajeva, "Till otrohetens försvar"; Klingberg; Nord 201). I frågan om otrohet av ideologiska skäl fick debatten en extra skjuts efter det som kallats the cultural turn inom översättningsvetenskapen (se t.ex. Hatim och Munday 102). En särskild inriktning var den feministiska översättningsvetenskapen som växte fram i Quebec på 1970-talet när feministiska översättare med inspiration från den framväxande genusvetenskapen började ifrågasätta hur kvinnor osynliggörs i litteraturen, inte minst språkligt. Många av dessa feminister inriktade sig på översättning av feministiska författare eller synliggörande av okända men betydelsefulla kvinnliga översättare, ofta i kombination med omfattande paratexter som lyfte fram det kvinnliga perspektivet i källtexten och den översatta texten (Godayol 173-181; von Flotow). För att ytterligare understryka sitt budskap och utmana det dominerande patriarkala språkbruket använde de sig gärna av feministisk ortografi, neologismer och ordlekar (Hatim och Munday 105; von Flotow 74-76). Strategierna var ibland så radikala att både feministerna själva och kritikerna talade om "manipulation" (Godard 49-50) eller "hijacking" (von Flotow 78) av texterna. Denna radikalism i kombination med den övervägande teoretiska inriktningen är förmodligen viktiga förklaringar till att den feministiska översättningspraktiken inte fått något större genomslag utanför den akademiska världen.

Feministisk översättning har också diskuterats med koppling till barnboksöversättning vid en konferens anordnad av det nordiska 
forskarnätverket NorChilNet år 2003 (se referat i Joosen m.fl.). Sedan Riitta Oittinen i sitt konferensbidrag lyft fram översättarens möjlighet till otrohet mot originaltexten kom diskussionen in på den feministiska översättningspraktiken som ett alternativ för att förändra den traditionella synen på språk och kön i barnböcker. Även om det framhölls i diskussionen att merparten av teorierna och metoderna inom feministisk översättning inte är direkt tillämpbara på barnboksöversättning, fick referatet av ordväxlingen (Joosen m.fl.) Göte Klingberg att replikera "att det måste finnas enklare sätt att förmedla feministisk ideologi till barn än genom att medvetet förfalska barnboksöversättningar" (13).

Genusproblematiken i översättningar har även aktualiserats av Cecilia Alvstad i ett avsnitt om rekommendationer till barnboksöversättare. Alvstad intar här en något annorlunda hållning än Klingberg och ger översättare rådet: "be attentive, be inclusive and do not produce or reproduce gender stereotypes that may inflict damage" (Alvstad 176). Hon skriver vidare att barnboksöversättare bör fundera över i vilka sammanhang det kan vara lämpligt att inta en normkritisk hållning till sin egen översättningspraktik (Alvstad 176). Alvstads inställning verkar därmed vara att det åligger översättaren att vara vaksam på könsperspektivet och, där så är möjligt, sträva mot könsneutrala och inkluderande måltexter. Det ska här understrykas att både Klingberg och Alvstad i första hand yttrar sig om skönlitterära barnböcker. Könsstereotypa framställningar i faktaböcker har mig veterligen aldrig tidigare behandlats inom svensk barnboksforskning.

Men det finns flera tecken som tyder på att det är särskilt angeläget att granska den ideologiska vinklingen i just faktaböcker. Bland annat nämner Marte Blikstad-Balas att flera studier visar att barn och ungdomar är benägna att läsa läroböcker och andra faktatexter förhållandevis okritiskt (108, 131-132), samtidigt som Ulla Damber framhåller att det är lättare för barn att ifrågasätta skönlitterära skildringar som har en tydlig och namngiven författarröst som förmedlar sin syn på världen (675). Den ideologiska granskningen måste dock göras med faktabokens speciella syften och framställningssätt för ögonen. Det finns all anledning att ansluta sig till Maria Nikolajeva som menar att faktaböcker "har så speciella drag att de över huvud taget inte kan diskuteras tillsammans med och på samma villkor som skönlitteratur" (Barnbokens byggklossar 36). Skillnaderna mellan skönlitteratur och faktaböcker gäller inte minst hur kön gestaltas. I skönlitterära barnböcker är skildringen av kön knuten till påhittade karaktärer i en fiktiv värld, medan icke-narrativa och icke-linjära 
faktatexter, som det här är fråga om, anlägger ett könsperspektiv på företeelser i den verkliga världen. Båda skildringarna har en stark potential att påverka läsarens föreställningar om genus, men den ideologiska vinklingen i faktaboken får en särskilt stark genomslagskraft om faktainnehållet formuleras som en objektiv och ovedersäglig sanning.

\section{Språk och genus i svenskan och franskan}

Innan vi går in på själva undersökningen ska några ord sägas om genus och könsneutralt skrivande ur ett svensk-franskt kontrastivt perspektiv. På franska gör sig nämligen genusfrågan ständigt påmind. Det finns inget neutralt genus motsvarande den/det, utan alla substantiv, animata såväl som inanimata, har antingen feminint eller maskulint genus. Detta påtvingade val framhävs av den framförställda artikeln (le/la; un/une) och den obligatoriska kongruensböjningen av en lång rad satskonstituenter. Vanligtvis sammanfaller biologiskt kön och grammatiskt genus när man talar om människor, men i övrigt är genustilldelningen arbiträr och baserad på ordets suffix eller etymologi. Det finns personbetecknande substantiv som kan vara både feminina och maskulina beroende på referens och som blir könsneutrala i plural (un eller une astronaute blir i plural des astronautes), men i många fall är exempelvis titlar och yrkesbeteckningar könsspecifika i både singular och plural: un acteur/des acteurs, une actrice/des actrices (skådespelare). Maskulina pronomen blir högfrekventa genom att $i l$ (han) används vid generisk referens, och den maskulina formen ils (de) är förstahandsalternativ i plural så länge minst en man omfattas av utsagan.

Även i Frankrike har könsneutralt skrivande debatterats länge, vilket resulterat i flera officiella riktlinjer publicerade från 1980-talet och framåt (Burr). Bland annat har man bestämt att den maskulina formen av yrkesbeteckningar och titlar ska brukas vid allmän referens i officiella texter i samband med offentliga tjänstetitlar, trots att dessa beteckningar i flertalet fall uppfattas som tydligt könsbestämda. Endast vid specifikt kvinnlig referens eller vid referens till enskilda personer kan den feminina formen tillämpas, som ett slags undantag (Burr 130; Rapport sur la féminisation 3, 15, 45). ${ }^{1}$ De maskulina yrkesbeteckningarna och titlarna leder sällan till missförstånd - det framgår i allmänhet av kontexten när det är båda könen som åsyftas - men kritiker menar att kvinnor konsekvent osynliggörs genom denna maskulina dominans (Burr 132; Viennot). Vid tillfällen då man särskilt vill betona att texten vänder sig till båda könen är det 
därför vanligt $\mathrm{i}$ icke officiella texter, särskilt i yrkeslivet, att tillgripa dubbel referens - till exempel il et elle (han och hon), les candidat(e)s (kandidaterna) eller chers collègues/chères collègues (kära kollegor) men i mer officiella sammanhang och i lagtext avråds från dubblering av tydlighetsskäl och av juridiska skäl (Burr 130; Rapport sur la féminisation 3; Usage d'un langage neutre 10). Könsneutralt skrivande väcker fortfarande starka känslor i alla läger i Frankrike, vilket visar hur stort symbolvärde de språkliga maskulinformerna har och att genusfrågan långt ifrån är löst (jfr Burr 132-134; Viennot).

I Sverige framställs bruket av samordningskonstruktioner (som hon och han) som något man helst bör undvika vid generisk referens (Språkriktighetsboken 78, 80; Myndigheternas skrivregler 67). Istället förordas andra lösningar vid ersättning av generiskt $h a n$, som införande av den (som), passivering, pluralformen de, upprepning av substantivet och olika typer av omskrivningar som gör pronomen överflödigt (Språkriktighetsboken 76-80; Milles 51-55). Det har även föreslagits att pronomenen han och man vid generisk syftning ska ersättas med hen respektive en (Milles 54-56). Även om användningen ökar av dessa nya former har de hittills inte fått något generellt genomslag. ${ }^{2}$ Precis som i Frankrike har bruket av titlar och yrkesbeteckningar varit föremål för debatt, och även i Sverige har man valt att låta maskulin form (lärare, skådespelare) utgöra huvudregel (med vissa undantag som sjuksköterska och barnmorska) istället för att införa dubbelformer som lärare och lärarinnor (Myndigheternas skrivregler 68). Dock är rekommendationen att undvika onödiga maskulina former på -man, som vetenskapsman, polisman och riksdagsman då dessa enkelt kan ersättas med exempelvis forskare, polis och riksdagsledamot (Språkriktighetsboken 87). Dessa råd är dock inte lika kontroversiella som i Frankrike eftersom merparten av de maskulina formerna uppfattas som icke könsidentifierande på svenska. Ett ytterligare skäl till att förorda de maskulina yrkestitlarna är att de feminina formerna (precis som på franska) ofta har en pejorativ klang och därför med fördel kan frångås i en modern kontext.

För en översättare är det viktigt att känna till såväl källspråkets som målspråkets normer och riktlinjer för könsneutralt skrivande för att kunna avgöra vad som är könsneutralt språkbruk och vad som är mer traditionella formuleringar, i synnerhet vid översättning mellan språk som svenska och franska där genussystemen och skrivtraditionerna skiljer sig markant. I den här artikeln är det endast effekten i de svenska måltexterna som analyseras. 


\section{Material och metod}

För den här undersökningen har tre faktaböcker för barn valts ut. Böckerna liknar varandra såtillvida att de alla bygger på fråga/svarsekvenser och ett rikt bildmaterial. Två av dem ingår dessutom i samma bokserie och vänder sig till barn i åldern 4-7 år: Laure Cambournacs och Françoise de Guiberts Mon premier Larousse des Pourquoi ? (2003) och Mon premier Larousse des Comment ? (2004). Böckerna tar upp olika ämnesområden som kan tänkas intressera yngre barn och är översatta till svenska av två olika översättare under titlarna Stora varförboken (2005, översatt av Ann Lewenhaupt) och Stora frågeboken (2011, översatt av Niels Halkjær). Den tredje boken, L'Espace (2008), marknadsförs under redaktörens namn, Émilie Beaumont, men texterna är skrivna av Christine Sagnier. Boken vänder sig till lite äldre barn i åldern 9-12 år och handlar om astronomi och rymdfärder. I Eva Sjöströms översättning från 2013 har den fått titeln Barnen frågar om rymden. Eftersom bilder, layout och sidnumrering är desamma i källtexterna och måltexterna kommer hänvisningar enbart att göras till den svenska upplagan. I Stora varförboken och Stora frågeboken samspelar text och bild, så att bilden kompletterar eller på ett ofta humoristiskt sätt kommenterar texten, till skillnad från i Barnen frågar om rymden där textens koppling till bildmaterialet är mindre direkt. Att just detta material valdes ut för undersökningen beror på att originaltexterna är skrivna på franska, ett språk som vi ovan sett kan försätta översättaren i många svåra valsituationer relaterade till språk och kön. Ett annat skäl var att texterna är relativt nyskrivna och översatta av olika översättare och att de genom sin textlängd, sitt förhållandevis avancerade språk och sitt rika ämnesinnehåll kan ge upphov till många typer av genusrelaterade översättningssvårigheter. Det är dessutom intressant att studera två snarlika böcker ur samma bokserie som översatts av olika översättare med delvis olika strategier. Huruvida texterna är representativa för faktabokskategorin mer generellt är dock en helt annan fråga, som är omöjlig att besvara utifrån det här begränsade urvalet. De exempel som excerperats ur texterna ska snarare uppfattas som illustrationer av mer eller mindre vanliga översättningsproblem, vilka i sin tur kan inspirera till liknande studier baserade på ett större textmaterial.

Undersökningsmetoden är främst explorativ i den meningen att materialet fått avgöra vilka kategorier som ligger till grund för studien. Källtexter och måltexter har systematiskt jämförts, och alla förekomster av könsspecifikt språk och skildringar av kön har noterats 
och analyserats. Därutöver har en mindre kvantitativ undersökning gjorts av böckernas bildmaterial.

\section{Bilder, språk och kön i tre faktaböcker för barn}

En översiktlig genomgång av materialet visar att bilderna i de tre faktaböckerna i huvudsak föreställer pojkar eller män. På omslaget till Barnen frågar om rymden syns inga människor alls, och på Stora frågebokens och Stora varförbokens omslag förekommer ett fåtal pojkar eller män. Bildmaterialet innanför pärmarna kan kategoriseras på följande sätt:

Tabell I. Könsbestämning av bildmaterialet.

\begin{tabular}{|l|c|c|c|c|c|c|}
\hline \multicolumn{2}{|c|}{} & \multicolumn{2}{|c|}{ Stora frågeboken } & \multicolumn{2}{c|}{ Stora varförboken } & \multicolumn{2}{c|}{$\begin{array}{c}\text { Barnen frågar om } \\
\text { rymden }\end{array}$} \\
\cline { 2 - 7 } & antal & $\%$ & antal & $\%$ & antal & $\%$ \\
\hline $\begin{array}{l}\text { Bilder } \\
\text { föreställande } \\
\text { enbart pojkar } \\
\text { eller män }\end{array}$ & 204 & 68 & 152 & 62 & 95 & 69 \\
\hline $\begin{array}{l}\text { Bilder } \\
\text { föreställande } \\
\text { enbart flickor } \\
\text { eller kvinnor }\end{array}$ & 26 & 9 & 21 & 9 & 35 & 26 \\
\hline $\begin{array}{l}\text { Bilder } \\
\text { föreställande } \\
\text { båda könen }\end{array}$ & 70 & 23 & 71 & 29 & 7 & 5 \\
\hline Totalt & 300 & 100 & 244 & 100 & 137 & 100 \\
\hline
\end{tabular}

I själva verket innehåller böckerna många fler bilder, men en stor mängd figurer kan inte könsbestämmas (till exempel förmänskligade djur, himlakroppar och artefakter, diverse fantasifigurer, människor med obestämbart kön) och har därför inte tagits upp i tabell 1.

Vad som heller inte framgår av tabell 1 beträffande Stora varförboken och Stora frågeboken är att pojkar och män är i majoritet på merparten av de bilder som föreställer båda könen. Flickorna och kvinnorna tenderar dessutom att inta en undanskymd, passiv eller könsstereotyp roll (syr, stickar, leker med dockor, lagar mat, tar hand om barn, hoppar hage och liknande). De maskulina aktörerna däremot är aktiva, roliga, busiga, uppfinningsrika, sportiga och äventyrliga, och dominerar särskilt i bilder av yrkeslivet. ${ }^{3}$ Denna traditionella gestaltning av kön förstärks som vi senare ska se verbalt i de franska källtexterna. 
Mansdominansen är påtaglig även i Barnen frågar om rymden. Om man i tabell 1 räknar bort 60 återkommande bilder, som föreställer en flicka eller en pojke som i halvfigur pekar på en faktaruta, återstår 65 bilder av enbart pojkar eller män respektive 5 bilder av enbart en flicka. Tre av bilderna föreställer en flicka som är aktivt involverad $i$ ett experiment, men endast en gång som självständig aktör (Beaumont, Rymden 40). På de två andra bilderna utförs den vetenskapliga aktiviteten i samarbete med en pojke (32) respektive en äldre manlig forskare (28). Med lite god vilja skulle många av de icke medräknade tecknade illustrationerna av astronauter i rymdkläder kunna tolkas som feminina (t.ex. 55, 56, 78, 79), men faktum kvarstår att det inte finns en enda tydlig bild av en vuxen kvinnlig astronaut eller forskare.

I jämförelse med de franska källtexterna i Larousse-serien innehåller den franska källtexten till Barnen frågar om rymden något fler inslag som skulle kunna betecknas som ett försök till inkludering av ett kvinnligt perspektiv. Till exempel används dubbel könsangivelse ibland, som ces hommes et ces femmes (dessa män och kvinnor) (Beaumont 100), och två korta passager $(61,91)$ tar upp kvinnors bidrag till det i övrigt mansdominerade utforskandet av rymden. Men utöver detta är det uteslutande män som namnges och enbart deras insatser som lyfts fram i texten.

I alla tre översättningarna finner man exempel på avsteg i förhållande till den franska källtexten, men av olika slag. Stora varförboken innehåller inslag av lokalisering (Cambournac och de Guibert, Varförboken 150) och ett antal mindre justeringar av faktaupplysningar. Bland annat finns det en precisering av årtal (6), ett tillägg om hur man får tag på ett graviditetstest (26) och ett kort klargörande av skillnaden mellan en snigel och en snäcka (84). Översättaren har också infört ett mer informellt tilltal än i den franska källtexten genom frekventa tillägg av du-tilltal, jag-form och vardagliga uttryck som jättestark, pytteliten och läskig. Ibland har meningar delats upp och språket förenklats, men i övrigt ligger översättningen relativt nära källtexten. Översättaren av Stora frågeboken har konsekvent förenklat språket men utan några tendenser till informalisering. Vidare har det språkliga tilltalet modifierats något så att barn-vuxendialogen blivit mer jämbördig. Det finns även små innehållsliga förändringar som verkar syfta till att utjämna ideologiska och kulturella skillnader snarare än att korrigera faktainformation (för en utförligare analys av denna bok, se Mossberg). Barnen frågar om rymden är den bok där flest innehållsliga förändringar skett i översättningen. Vid flera tillfällen har bitar av text strukits (se t.ex. Beaumont, Rymden 15, 62, 122), lagts till (t.ex. 29, 48) eller skrivits om (t.ex. 6, 16, 46, 76). I de fles- 
ta fall verkar det bero på att man velat uppdatera fakta (till exempel om Uranus ringar 28), ge utförligare förklaringar (till exempel om tektoniska plattor 14) eller lokalisera texten till svenska förhållanden (till exempel svensk rymdindustri och utbildning 84-86). I övrigt är översättningen av Barnen frågar om rymden tämligen källtextnära, även om de många metaforerna, ordlekarna och idiomen, som sätter en stark prägel på den franska källtexten, i flera fall är strukna eller omvandlade till icke-bildliga uttryck.

I samtliga böcker måste översättarna ta viss hänsyn till bildmaterialet och hålla sig inom det avdelade textutrymmet. Trots de snäva ramarna innehåller alla översättningarna exempel på smidiga könsneutrala och inkluderande översättningslösningar som inte motsäger bildmaterialet, men det finns även ställen där översättarna behållit könsbestämda uttryck utan att det är nödvändigt, och vid några tillfällen till och med infört nya könsspecificeringar utan motsvarighet i källtexten.

\section{Könsneutral översättning - hur då?}

En första ordkategori som aktualiserar frågan om könsneutral översättning är yrkestitlar. I alla tre böckerna har de franska yrkesbeteckningarna scientifiques och chercheurs (forskare) ibland översatts med vetenskapsmän vid generisk referens, något som exempelvis Språkriktighetsboken (82, 87), Karin Milles (42) och Myndigheternas skrivregler (68) avråder från, med hänvisning till att många språkbrukare uppfattar ord som slutar på -man som maskulint könsbestämda. Vid denna typ av yrkesbeteckningar finns det dessutom gott om könsneutrala alternativ på svenska (forskare, specialister, experter; i specifika kontexter även astronomer, geologer och så vidare), som på ett smidigt sätt kan ersätta de könsbestämda uttrycken. En könsneutral lösning hade inte heller behövt leda till någon motstridighet mellan text och bild (för en kategorisering av samspelet mellan text och bild, se till exempel Nikolajeva, Bilderbokens pusselbitar 22) eftersom texterna så gott som uteslutande handlar om icke-namngivna personer och inte alltid är knutna till en bild med könsbestämda personer.

Andra formuleringar som kan göras mer könsneutrala på svenska är bruket av feminina yrkesbeteckningar och generiskt maskulint pronomen. Ett sådant exempel finns i Stora varförboken, där översättaren vid ett tillfälle låtit sig påverkas av den franska källtextens dubblering - maîtres et maîtresses - och hamnat i en formulering som man numera avråder från: "lärare och lärarinnor" (Cambournac och de Guibert, Varförboken 151; jfr Myndigheternas skrivregler 68). I Barnen 
frågar om rymden används ofta könsneutrala pluralformer istället för könsbestämda singularformer i såväl källtext som måltext när yrken som meteorologer, piloter och astronauter kommer på tal (på svenska i kombination med det könsneutrala pronomenet $d e$ ), men effekten av detförtasnär den svenska översättningenföljer den franska källtexten och plötsligt anger att "meteorologerna vill leka trollkarlar" (Beaumont, Rymden 110) och därigenom underförstår att meteorologer egentligen bara är män. När singular används händer det också att ord som piloten och astronauten ersätts med pronomenet han vid generisk referens, som i följande textpassage (i fortsättningen ges en direktöversättning av den franska källtexten inom hakparenteser) ${ }^{4}$ :

(1) Quand il inspire, l'astronaute consomme de l'oxygène. En expirant, il rejette du gaz carbonique. Si l'air du vaisseau n'était pas renouvelé en permanence, il suffoquerait.

[När han andas in konsumerar astronauten syre. När han andas ut släpper han ut koldioxid. Om luften i rymdfarkosten inte förnyades hela tiden skulle han kvävas.]

Astronauten gör av med syre när han andas. När han andas ut släpper han ut koldioxid, och om luften inte förnyades hela tiden skulle han kvävas. (Beaumont, Rymden 89)

Här hade det varit möjligt att exempelvis välja pluralbildning på svenska och på så sätt undvika en könsstereotyp framställning av astronautyrket. Som ofta är fallet i Barnen frågar om rymden finns det inte någon direkt tillhörande bild som skulle motsäga en sådan språklig justering.

Ett annat exempel på könsspecifik referens i samma bok är följande citat:

(2) Il n'est pas donné à tout le monde d'être astronaute. Les candidats, hommes et femmes, sont recrutés dans le monde entier. Seuls les meilleurs partent, soit à bord de la fusée russe Soyouz, soit à bord de la navette américaine.

[Det är inte alla givet att vara astronaut. Kandidaterna, män och kvinnor, rekryteras från hela världen. Endast de bästa ger sig iväg, antingen ombord på den ryska rymdfarkosten Sojuz eller ombord på den amerikanska rymdfärjan.]

Vem som helst kan inte bli astronaut. Kandidaterna, både män och kvinnor, rekryteras från hela världen. Och bara de allra bästa får bli besättningsmän. (Beaumont, Rymden 88) 
På franska ser man här att författaren bemödat sig om att synliggöra kvinnor genom tillägget hommes et femmes efter det maskulina substantivet candidats i generisk betydelse. Men på svenska får den oväntade dubbleringen ("män och kvinnor") snarast omvänd effekt eftersom kandidater redan är könsneutralt på svenska. Dessutom slås det fast i nästa andetag att det egentligen bara är "besättningsmän" som kan komma i fråga. Med en enkel strykning av substantivet besättningsmän och en försiktig omskrivning - till exempel "Men det är bara de allra bästa som får chansen" - hade passagen blivit betydligt mer inkluderande utan att man frångått källtextens betydelse.

I fråga om feminina yrkesbeteckningar och generiskt maskulint pronomen har översättaren av Stora frågeboken, till skillnad från de övriga översättarna, i flera fall valt en könsneutral översättning. Exempelvis har översättaren låtit feminina substantiv, som danseuse (dansös) och championnes de patin à glace (konståkerska), bli" dansare" respektive" isdansare" (Cambournac och de Guibert, Frågeboken 54). Effekten av denna strävan förtas i viss mån av att endast en kvinnlig isdansare förekommer på bild (dock finns det både en manlig och en kvinnlig dansare), men det underförstås åtminstone i texten att konståkning och dans är något som både män och kvinnor ägnar sig åt. Andra tekniker för könsneutral översättning i Stora frågeboken är införande av kollektivt substantiv (franskans le chirurgien et son équipe, den [manlige] kirurgen och hans team, blir på svenska "operationspersonalen" 125), användning av varierad eller identisk upprepning av substantivet (franskans le peintre - il, målaren - han, blir på svenska "målaren - konstnären" 58), införande av den som (franskans au malade, den [manlige] sjuke, blir på svenska "den som blir opererad" 125) och passivkonstruktioner som gör generiskt han överflödigt (franskans Il donne le rythme, han anger rytmen, blir på svenska "En orkester leds av en dirigent" 57). Ibland kombinerar översättaren flera tekniker, som i den svenska måltexten nedan, där det finns en växling mellan passivering ("Blodprov tas") och varierad upprepning av yrkesbeteckningen ("Sjuksköterskan", "Sköterskan"):

(3) Comment on fait une prise de sang? L'infirmière pose un garrot sur le bras : elle l'entoure avec un gros élastique, ce qui fait gonfler les veines. Elle glisse une aiguille très fine dans la veine au creux du coude et elle récupère le sang dans un petit tube.

[Hur tar man ett blodprov? Sjuksköterskan lägger ett tryckförband runt armen: hon omger det med ett tjockt gummiband, vilket får ådrorna att svälla. Hon sticker en mycket fin nål $i$ ådern i armbågsvecket och samlar blodet i ett litet rör.] 
Hur tas ett blodprov? Blodprov tas ofta i armbågsvecket. Sjuksköterskan lägger då ett band runt armen och spänner åt det. Då sväller blodådrorna och syns tydligt under huden. Sköterskan sticker i en åder med en fin ihålig nål och tappar ut lite blod. (Cambournac och de Guibert, Frågeboken 124)

Bilden i exempel 3 är dessutom av en sådan karaktär att det knappast är möjligt att könsbestämma sjuksköterskan, vilket gör hela yrkesbeskrivningen, text såväl som bild, könsneutral på svenska.

Vid skildringen av läkaryrket kommer samma översättare ifrån genusdilemmat genom att välja pluralbildning i kombination med ganska radikala omskrivningar av måltexten. Inte heller i detta fall leder den könsneutrala strategin till några motsägelser mellan text och bild eftersom texten är hämtad från en faktaruta utan tillhörande bild:

(4) Bras cassé, fièvre ou brûlure, le médecin voit en priorité les malades qui ont les problèmes les plus graves. C'est pour cela qu'il faut parfois attendre longtemps! Quand cela est nécessaire, il demande au malade de rester à l'hôpital, c'est l'hospitalisation.

[Bruten arm, feber eller brännskada, läkaren (maskulinum) träffar först de sjuka som har allvarligast problem. Det är därför man ibland måste vänta länge! När det är nödvändigt ber han den sjuke (maskulinum) att stanna kvar på sjukhuset, det är sjukhusinläggning.]

Dit kommer folk som har råkat ut för olyckor, och dit kan man åka om man plötsligt blir sjuk eller skadar sig. Läkarna avgör vilka som snabbast behöver behandling. Därför kan andra få vänta ett tag. (Cambournac och de Guibert, Frågeboken 125)

\section{Inkluderande översättning - hinder och möjligheter}

På samma sätt som det är möjligt att uppnå en mer könsneutral översättning av yrkesbeteckningar och undvika generiskt han går det att med förhållandevis små ingrepp åstadkomma en mer inkluderande översättning. Med "inkluderande" avses i detta sammanhang en mer jämställd formulering eller införande av ett kvinnligt perspektiv i översättningen.

Ett exempel på när en mer inkluderande översättning skulle kunna vara aktuell är en passage i Barnen frågar om rymden där en orsak anges till kvinnors låga deltagande i utforskandet av rymden. I den franska källtexten nedan förklaras det låga antalet kvinnliga astronauter med att färre kvinnor väljer en naturvetenskaplig karriär. Genom att det tidigare mycket utförligt förklarats att det är nödvändigt 
med en gedigen naturvetenskaplig utbildning (Beaumont, Rymden 85), kan man i den franska texten dra slutsatsen att det är av den anledningen som det finns betydligt färre kvinnor att välja bland vid astronaututtagningar. I den svenska översättningen kan man istället få uppfattningen att kvinnor gör ett aktivt val att inte bli astronauter och att det är därför de bara utgör "en bråkdel":

(5) En principe, le métier est ouvert aux hommes comme aux femmes, majeurs, mais il y a moins de filles qui choisissent de faire une carrière scientifique. Aujourd'hui, il n'y a qu'une femme astronaute dans l'équipe de l'ESA.

[I princip är yrket öppet för både män och kvinnor, som är myndiga, men det är färre flickor som väljer en naturvetenskaplig karriär. Idag finns det bara en kvinnlig astronaut i ESA.]

Yrket är öppet för både män och kvinnor, men det är färre kvinnor som väljer att bli astronauter. Idag utgör de kvinnliga astronauterna bara en bråkdel. (Beaumont, Rymden 91)

Kanske hade det i detta fall varit bättre att välja en mer källtextnära översättning och tydligare precisera att färre flickor väljer en naturvetenskaplig utbildning och att det är därför som det inte finns så många kvinnliga astronauter.

Även i Stora varförboken finns passager där en mer inkluderande översättning skulle ha kunnat tillämpas. En sådan är exempel 6 nedan, där ett minimalt ingrepp i texten skulle ha resulterat i en mer jämställd och mindre heteronormativ syn på föräldraskap:

(6) Après la naissance d'un enfant, un des parents arrête parfois de travailler pour s'occuper du bébé. C'est souvent la maman. Quand les enfants ont grandi, elle reprend son travail ou non.

[Efter ett barns födelse slutar ibland en av föräldrarna att arbeta för att ta hand om barnet. Det är ofta mamman. När barnen vuxit upp återupptar hon sitt arbete, eller inte.]

När ett barn föds finns det föräldrar som stannar hemma från jobbet för att ta hand om det. Oftast mamman. När barnen blir större kan föräldern börja jobba igen, men inte alltid. (Cambournac och de Guibert, Varförboken 152)

Här hade det varit enkelt att stryka meningen "Oftast mamman" eller kanske skriva "Oftast turas föräldrarna om", och eventuellt stry- 
ka den sista meningen. Exempel 6 kan jämföras med ett utdrag ur Stora frågeboken där översättaren i en faktaruta (utan tillhörande bild) valt att tona ner personernas könsidentifierande drag och därmed förmedlar en mer inkluderande familjeskildring:

(7) Dans le ventre de sa maman, le bébé peut entendre des sons : le bruit du cœur de sa maman bien sûr, la voix grave de son papa, celle de son grand frère ou de sa grande sœur, mais aussi les musiques que sa maman écoute.

[I mammans mage kan barnet (maskulin form) höra ljud: ljudet av mammans hjärta naturligtvis, pappans mörka röst, storebrors eller storasysters röst, men också musik som mamman lyssnar på.]

Barnet kan höra ljud när det ligger inne i mammans mage: mammans hjärta som slår, pappan och syskonen som pratar. Till och med musik som familjen lyssnar på därute. (Cambournac och de Guibert, Frågeboken 29)

I detta fall har syskonens kön neutraliserats och omnämnandet av pappans mörka röst utelämnats i översättningen. Dessutom har alla familjemedlemmar involverats mer i graviditeten genom att det är familjen som tillsammans lyssnar på musik. Med relativt små ingrepp och utan att det uppstår någon direkt motstridighet i förhållande till en bild har alltså översättaren tonat ner mammans roll till förmån för ett mer jämställt familjeliv och en mer könsbalanserad framställning.

I Stora frågeboken händer det vidare att översättaren lägger till kvinnliga aktörer utan motsvarighet i källtexten, vilket får till effekt att kvinnliga erfarenheter försiktigt synliggörs. Ett sådant exempel är det svenska tillägget av ordet pigor när de i övrigt manliga invånarna i de gamla riddarborgarna räknas upp (Cambournac och de Guibert, Frågeboken 22). På liknande vis poängterar översättaren i en annan textpassage att både drottningar och kungar bodde i slott förr i tiden (24), och inte bara kungar som i den franska texten. När tronföljden förklaras gör översättaren flera tillägg som utan direkt motsvarighet i källtexten synliggör kvinnor i den svenska översättningen, till exempel genom att precisera att inte bara pojkar blev kungar förr utan att också "En dotter kunde bli drottning om det inte fanns söner" (24), att både kungar och drottningar har vissa representationsplikter som regenter (25) och att Sveriges kronprinsessa inte är gift med en kunglig person (25). Giftermål beskrivs också som mer jämställt i den svenska texten genom att det inte är prinsar som 
gifter sig med prinsessor, som i den franska texten, utan prinsar och prinsessor som gifter sig "med varandra" (25). Genom att tilläggen i dessa exempel inte inför någon motsättning mellan text och bild är de förhållandevis oproblematiska. I två fall $(22,24)$ är det till och med så att den svenska texten, i motsats till den franska, framhäver de kvinnliga personer som faktiskt förekommer på bilden: på sidan 22 visas en riddarborg med både manliga och kvinnliga invånare och på sidan 24 en kung med en son i knät och en dotter vid sin sida.

Svårare är det att förändra den underliggande ideologin i längre textavsnitt som förmedlar en könsstereotyp syn i såväl text som bild. I följande exempel har översättaren av Stora varförboken valt en ganska källtextnära översättning:

(8) Pourquoi les garçons sont plus bagarreurs que les filles ? C'est une question difficile! Les garçons ont un peu plus tendance à se bagarrer mais, en plus, on les y encourage. On leur fait des compliments sur leur force, on leur offre des pistolets, des épées alors qu'on donne plutôt des poupées aux filles.

[Varför är pojkar bråkigare än flickor? Det är en svår fråga! Pojkar har en lite större tendens att slåss men man uppmuntrar dem dessutom till det. Man ger dem komplimanger för deras styrka, man ger dem pistoler och svärd medan man snarare ger dockor till flickor.]

Varför slåss pojkar mer än flickor? Det är en svår fråga. Pojkar brukar vara lite stökigare, men det beror ofta på att vuxna uppmuntrar dem. Pojkar lär sig att det är bra att vara stark. De får ofta leksaker som pistoler och svärd att slåss med, medan flickor får dockor som de kan pyssla med. (Cambournac och de Guibert, Varförboken 149)

Det underliggande antagandet i frågan ovan, att pojkar och flickor beter sig olika, kan lätt uppfattas som onyanserat av en svensk läsare. Troligen är det därför översättaren gjort en del nedtoningar av den franska textens formuleringar (lite större tendens att slåss > "lite stökigare"; Man ger dem komplimanger för deras styrka > "Pojkar lär sig att det är bra att vara stark"). Men det är ändå möjligt att en del högläsande vuxna skulle ställa sig frågande till det något kategoriska påståendet att pojkar ofta uppfostras till att bli "lite stökigare" och får "pistoler och svärd att slåss med", till skillnad från flickor som uppmuntras till att vara mer omhändertagande och leka med dockor. Exemplet utgör dock en stor utmaning för översättaren, inte minst genom att den svenska formuleringen måste passa ihop med en bild av två pojkar i vilt slagsmål och två flickor som betraktar var- 
andra med ett skenheligt leende och ett hjärta mellan sig, samtidigt som den ena har en kniv och den andra en tång bakom ryggen.

Exempel 8 kan jämföras med ett utdrag ur Stora frågeboken, där den svenska översättaren valt en helt annan väg och tagit sig stora friheter i förhållande till källtexten:

(9) Pourquoi les filles et les garçons ne jouent pas aux mêmes jeux ? Les enfants aiment bien jouer avec des jouets qui imitent les gestes de leurs parents : le garage et le foot comme papa pour les garçons, la dînette comme maman pour les filles. Même s'il y a beaucoup de mamans qui conduisent et des papas qui font très bien la cuisine, un papa et une maman donnent rarement une voiture à leur fille et une dînette à leur fils.

[Varför leker inte flickor och pojkar samma lekar? Barn tycker om att leka med leksaker som härmar föräldrarnas aktiviteter: garage och fotboll som pappa för pojkarna, leksaksservis som mamma för flickorna. Även om det finns många mammor som kör bil och pappor som är mycket duktiga på att laga mat ger en pappa och en mamma sällan en bil till sin dotter och en leksaksservis till sin son.]

Dockor för flickor och bollar för pojkar? Barn härmar det som vuxna gör. Förr lagade oftast mammorna all mat och tog hand om barnen, medan papporna körde bilen och gick på fotboll. Då lekte flickor med dockor och leksaksspisar, och pojkar med leksaksbilar och bollar. Idag är det annorlunda - pappor lagar mat och mammor kör bil. Och flickor spelar fotboll och pojkar leker att de lagar mat. (Cambournac och de Guibert, Frågeboken 45)

Både exempel 8 och 9 inleds på franska med en fråga som genom sitt implicita antagande att pojkar och flickor alltid är på ett visst sätt förstärker de rådande mönstren. Istället för att reproducera denna könsstereotypa föreställning i exempel 9 ifrågasätter översättaren den ("Dockor för flickor och bollar för pojkar?") och övergår därefter till att explicit förklara att synen på kön såg ut på ett visst sätt förr i tiden men att det idag är helt annorlunda. Det kan noteras att översättaren använder sig av ungefär samma betydelseelement som i den franska texten men presenterar stoffet ur en annan synvinkel och drar helt andra slutsatser. Texten kompletteras i denna fråga/svarsekvens av en bild som visar en pojke som dribblar med en fotboll och en flicka som leker med en docka. Text och bild kompletterar alltså varandra i källtexten, men motstridigheten som uppstår i den svenska måltexten skulle kunna tolkas som en inbjudan till kritisk eftertanke. 


\section{Könsneutral och inkluderande översättning eller feministisk manipulation?}

Undersökningen har visat att de tre översättarna har olika benägenhet att frigöra sig från källtexten i riktning mot en mer inkluderande och könsneutral översättning. Översättarna av Barnen frågar om rymden och Stora varförboken inför relativt sällan mer könsneutrala eller inkluderande formuleringar än i källtexten. Samtidigt visar översättningen av Stora frågeboken att en mer jämställd framställning inte alls är en utopi vid översättning av faktaböcker för barn. Mycket kan åstadkommas med förhållandevis små medel.

Frågan om hur fri en barnboksöversättning får vara är förstås kontroversiell (jfr Klingberg; Nikolajeva, "Till otrohetens försvar"), men jag menar att de översättningsstrategier som presenterats här knappast skulle kunna karakteriseras som feministiskt "manipulativa" i Godards mening (49-50) eller, med Klingbergs ord (13), som ett sätt att "förfalska" texten. Faktaboksöversättarens mål är ju inte i första hand att återskapa källtextförfattarens konstnärliga uttryckssätt, utan att på ett sakligt och objektivt sätt och i samklang med sin tid och sin kultur överföra information om den verkliga världen. Snarare har textanalysen gett idéer till hur man skulle kunna gå ännu längre i riktning mot en mer könsneutral och inkluderande skildring, utan att faktabokens syfte förvanskas eller att det uppstår en obegriplig motsättning mellan text och bild. I synnerhet faktarutorna hade kunnat utnyttjas mer för att uppnå en balans mellan könen eftersom de ofta skrivs om och inte är kopplade till en bild som begränsar textinnehållet. Exempelvis hade man kunnat introducera fler kvinnliga aktörer, när man ändå ändrar faktainnehållet $\mathrm{i}$ texterna, och då och då ännu tydligare skriva fram att såväl kvinnor som män kan ägna sig åt dans, måleri och konståkning och välja yrken som astronaut, sjuksköterska och forskare. I takt med att vår syn på språk och kön utvecklas och förändras kommer det förmodligen att bli aktuellt att finna mer långtgående översättningslösningar än vad som diskuterats här.

Biografisk information: Mari Mossberg är lektor i översättning vid Språkoch litteraturcentrum, Lunds universitet. År 2006 disputerade hon i fransk språkvetenskap på en avhandling om franska och svenska koncessiva konnektorer $i$ kontrastiv belysning. Hennes fortsatta forskning har handlat om översättning och kontrastiva skillnader mellan svenskan och franskan. Hon är koordinator för Lunds universitets översättarprogram och undervisar $i$ översättning, svenska som främmandespråk och svenska som andraspråk. 


\section{Noter}

1 Övriga franskspråkiga länder har i många fall valt andra lösningar (Rapport sur la féminisation, 17-23).

2 Om användningen av könsneutralt hen i skönlitterära barnböcker, se t.ex Grönblad.

3 Jfr Iversen (77) som också funnit att könsstereotyper lever kvar i gestaltningen av yrkesroller i brittiska bildordböcker för barn. Iversen hänvisar i sin tur till flera andra undersökningar av könstilldelning i bilderböcker.

4 Direktöversättningarna är gjorda av artikelförfattaren och tänkta som vägledning för en icke franskkunnig läsare. De ligger strukturellt och lexikalt så nära originaltexten som möjligt, utan några försök till idiomatik.

\section{Litteratur}

Alvstad, Cecilia. "Children's Literature". The Routledge Handbook of Literary Translation, redigerad av Kelly Washbourne och Ben Van Wyke, Abingdon, Routledge, 2019, s. 159-180.

Beaumont, Émilie och Christine Sagnier. L'Espace [Rymden]. Paris, Fleurus, 2008.

---. Barnen frågar om rymden. Översatt av Eva Sjöström, Stockholm, Hippo, 2013.

Blikstad-Balas, Marte. Literacy $i$ skolan. Översatt av Susanne Uhler, Lund, Studentlitteratur, 2018.

Bokprovning på Svenska barnboksinstitutet. En dokumentation. Årgång 2020. Svenska barnboksinstitutet, 2020, www.barnboksinstitutet.se/ wp-content/uploads/2021/04/Dokumentation-2021.pdf. Hämtad 6 maj 2021.

Burr, Elisabeth. "Gender and Language Politics in France". Gender across Languages. The Linguistic Representation of Women and Men. Vol. 3, redigerad av Marlis Hellinger och Hadumod Bussmann, Amsterdam, Benjamin, 2003, s. 119-140.

Cambournac, Laure och Françoise de Guibert. Mon premier Larousse des Comment? [Min första Larousse om Hur?]. 2004. Paris, Larousse, 2013.

---. Mon premier Larousse des Pourquoi ? [Min första Larousse om Varför?]. 2003. Paris, Larousse, 2013.

---. Stora frågeboken. Översatt av Niels Halkjær, Stockholm, Rabén \& Sjögren, 2011. 
---. Stora varförboken. Översatt av Ann Lewenhaupt, Stockholm, Rabén \& Sjögren, 2005.

Damber, Ulla. "Om tidig läsutveckling i det mångspråkiga samhället". Svenska som andraspråk. I forskning, undervisning och samhälle, redigerad av Kenneth Hyltenstam och Inger Lindberg, Lund, Studentlitteratur, 2013, s. 661-684.

Edlund, Ann-Cathrine, Eva Erson och Karin Milles. Språk och kön. Stockholm, Norstedts akademiska förlag, 2007.

Godard, Barbara. "Theorizing Feminist Discourse/Translation". Tessera, vol. 6, 1989, s. 42-53, doi.org/10.25071/1923-9408.23583.

Godayol, Pilar. "Gender and Translation". The Routledge Handbook of Translation Studies, redigerad av Carmen Millán och Francesca Bartrina, Abingdon, Routledge, 2013, s. 173-185.

Graeske, Caroline. "Värdefull eller värdelös? Om värdegrund och genus i läromedel i svenska". Tidskrift för litteraturvetenskap, nr 3-4, 2010, ojs.ub.gu.se/ojs/index.php/tfl/article/view/510. Hämtad 31 mars 2021.

Grönblad, Fatima. "Hen hjälpte henne". Språktidningen, nr 6, 2017, s. 18-23.

Hatim, Basil och Jeremy Munday. Translation. An Advanced Resource Book. Abingdon, Routledge, 2004.

Iversen, Sarah Hoem. "The (Re)presentation of Knowledge about Gender in Children's Picture Dictionaries". Verbal and Visual Strategies in Nonfiction Picturebooks. Theoretical and Analytical Approaches, redigerad av Nina Goga, Sarah Hoem Iversen och Anne-Stefi Teigland, Oslo, Scandinavian University Press, 2021, s. 67-79, www.idunn.no/ verbal_and_visual_strategies_in_nonfiction_picturebooks. Hämtad 17 maj 2021.

Joosen, Vanessa, Sylvia Liseling Nilsson och Jana Pohl. "EnGendering Translation Theory. A Report about a NorChilNet Symposium". Barnboken - tidskrift för barnlitteraturforskning, vol. 27, nr 1, 2004, s. 58-60.

Klingberg, Göte. "Trohet och otrohet. En kommentar om barnboksöversättningsteori". Barnboken - tidskrift för barnlitteraturforskning, vol. 27, nr 2, 2004, s. 10-13.

Milles, Karin. Jämställt språk. En handbok i att skriva och tala jämställt. 2 uppl., Stockholm, Norstedt, 2012. 
Mossberg, Mari. "Att översätta faktaböcker för barn. Om textuell, interpersonell och innehållslig anpassning". Språk och stil, vol. 30, 2020, s. 235-264.

Myndigheternas skrivregler. 8 uppl., Stockholm, Språkrådet, 2014, www.isof.se/om-oss/publikationer/institutets-publikationer/ sprakvard/2016-09-14-myndigheternas-skrivregler.html. Hämtad 17 februari 2020.

Nikolajeva, Maria. Barnbokens byggklossar. 3 uppl., Lund, Studentlitteratur, 2017.

---. Bilderbokens pusselbitar. Lund, Studentlitteratur, 2000.

---. "Till otrohetens försvar. Om att svika texten till förmån för barnläsaren". Barnboken - tidskrift för barnlitteraturforskning, vol. 27, nr 1, 2004, s. 23-32.

Nord, Christiane. "Functionalism in Translation Studies". The Routledge Handbook of Translation Studies, redigerad av Carmen Millán och Francesca Bartrina, Abingdon, Routledge, 2013, s. 201-212.

Ohlander, Ann-Sofie. Kvinnor, män och jämställdhet $i$ läromedel $i$ historia. En granskning på uppdrag av Delegationen för jämställdhet $i$ skolan (SOU 2010:10). Rapport I. Stockholm, Fritze, 2010, www.regeringen. se/rattsliga-dokument/statens-offentliga-utredningar/2010/02/ sou-201010. Hämtad 31 mars 2021.

---. Kvinnor, män och jämställdhet $i$ läromedel $i$ samhällskunskap. En granskning på uppdrag av Delegationen för jämställdhet $i$ skolan (SOU 2010:33). Rapport II. Stockholm, Fritze, 2010, www.regeringen.se/ rattsliga-dokument/statens-offentliga-utredningar/2010/05/sou201033. Hämtad 31 mars 2021.

O'Sullivan, Emer. Comparative Children's Literature. Översatt av Anthea Bell, Abingdon, Routledge, 2005.

Rapport sur la féminisation des noms de métier, fonction, grade ou titre. Commission générale de Terminologie et de Néologie, 1998, www. vie-publique.fr/rapport/24678-rapport-sur-la-feminisation-desnoms-de-metier-fonction-grade-ou-titre. Hämtad 17 februari 2020.

Skolverket. I enlighet med skolans värdegrund? En granskning av hur etnisk tillhörighet, funktionshinder, kön, religion och sexuell läggning framställs i ett urval av läroböcker. Rapport 285. Stockholm, Skolverket, 2006, www.skolverket.se/publikationsserier/rapporter/2006/i-enlighet-med-skolans-vardegrund?id=1659. Hämtad 31 mars 2021. 
---. Läroplan för förskolan. Lpfö 18. Stockholm, Skolverket, 2018, www.skolverket.se/publikationsserier/styrdokument/2018/laroplan-for-forskolan-lpfo-18. Hämtad 26 november 2020.

---. Läroplan för grundskolan samt för förskoleklassen och fritidshemmet. Lgr 11. Stockholm, Skolverket, 2019, www.skolverket.se/undervisning/grundskolan/laroplan-och-kursplaner-for-grundskolan/laroplan-lgr11-for-grundskolan-samt-for-forskoleklassen-och-fritidshemmet. Hämtad 26 november 2020.

Språkriktighetsboken. 2 uppl., Malmö, Språkrådet och Nationalencyklopedin, 2016.

Usage d'un langage neutre du point de vue du genre au Parlement Européen [Användning av ett könsneutralt språk i Europaparlamentet]. Europaparlamentet, 2018, www.europarl.europa.eu/cmsdata/187098/ GNL_Guidelines_FR-original.pdf. Hämtad 27 november 2020.

Viennot, Éliane. Le langage inclusif. Pourquoi, comment? [Inkluderande språk. Varför, hur?]. Donnemarie-Dontilly, Éditions iXe, 2018.

von Flotow, Luise. "Feminist Translation. Contexts, Practices and Theories". TTR. Traduction, Terminologie, Rédaction, vol. 4, nr 2, 1991, s. 69-84, id.erudit.org/iderudit/037094ar. Hämtad 12 februari 2020. 